\title{
Amir KRPIĆ
}

\section{Izvještaj sa tribine \\ REFERENDUM ZA NEZAVISNOST \\ REPUBLIKE BOSNE I HERCEGOVINE - 26 godina poslije, Tuzla, 28. februar 2018. godine}

Dana 28. februara 2018. godine u amfiteatru A2 Filozofskog fakulteta Univerziteta u Tuzli organizovana je tribina Referendum za nezavisnost Republike Bosne i Hercegovine - 26 godina poslije, povodom 1. marta, Dana nezavisnosti Bosne i Hercegovine. Organizatori tribine bili su: Odsjek za historiju Filozofskog fakulteta Univerziteta u Tuzli, Arhiv Tuzlanskog kantona, Društvo arhivskih zaposlenika Tuzlanskog kantona, Centar za istraživanje moderne i savremene historije Tuzla i Društvo historičara Tuzlanskog kantona.

U prostorijama Filozofskog fakulteta, prije tribine, upriličena je izložba pod nazivom Obnova i priznanje Bosne i Hercegovine na temeljima milenijskog kontinuiteta u organizaciji Arhiva Tuzlanskog kantona. Izložbu je otvorio mr. sc. Omer Zulić, direktor Arhiva Tuzlanskog kantona.

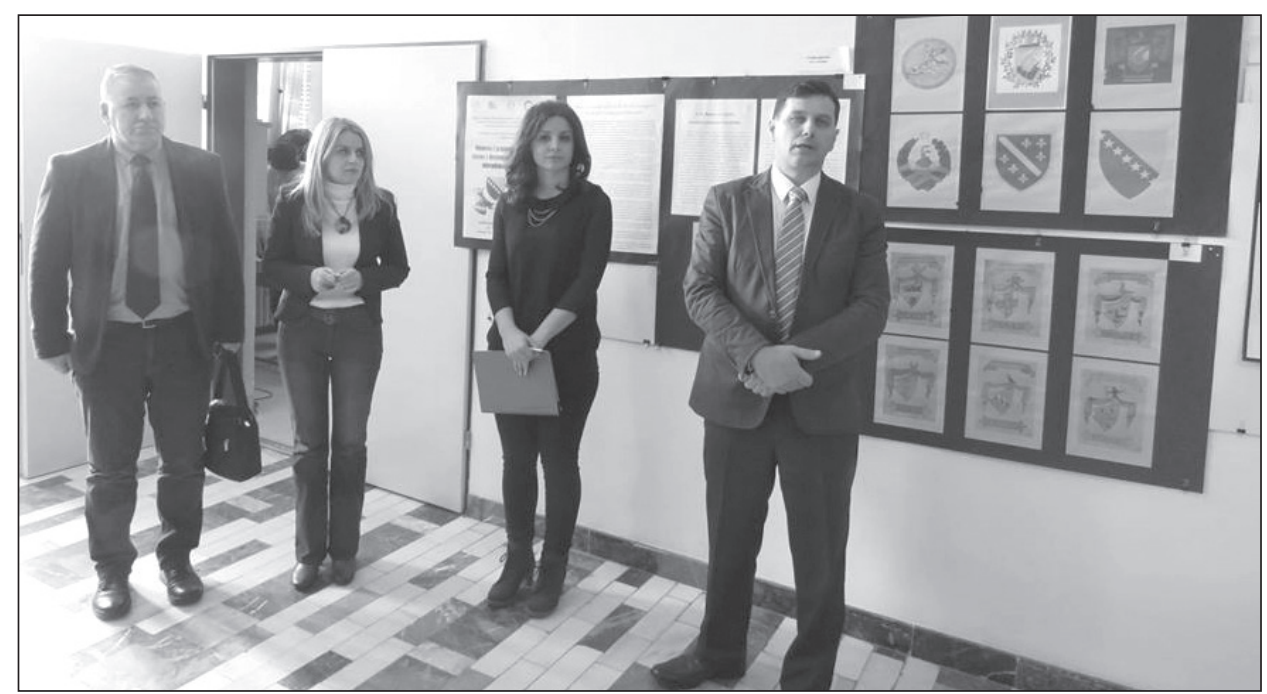

Prilog 1. Detalj sa otvaranja izložbe Obnova i priznanje Bosne i Hercegovine na temeljima milenijskog kontinuiteta

Ova tribina je jedinstvena po tome što su njeni inicijatori, autori referata $\mathrm{i}$ izlagači bili studenti prvog i trećeg ciklusa na Odsjeku za historiju, uz mentorstvo 
profesora sa Odsjeka za historiju. Moderator tribine bila je studentica četvrte godine studija na Odsjeku za historiju, Edna Čavalić, dok su izlagači bili Ahmo Mehmedović i Amir Krpić sa četvrte godine studija, te mr. Semir Hadžimusić sa prve godine trećeg ciklusa studija.

Tribinu je u ime organizatora otvorio voditelj Odsjeka za historiju i direktor Centra za istraživanje moderne i savremene historije Tuzla, prof. dr. Sead Selimović. Prvi referat je, uz recenziju dr. sc. Senaida Hadžića, vanr. prof. izlagao Ahmo Mehmedović, a referat je nosio naslov Historijski značaj referenduma za nezavisnost Republike Bosne i Hercegovine. Mehmedović je ukazao na osnovne činjenice i najvažnije informacije o referendumu za nezavisnost Republike Bosne i Hercegovine. Riječ je o onim činjenicama i informacijama koje je potrebno neprestano ponavljati kako bi se sačuvala i dodatno razvila svijest o značaju pomenutog referenduma. To se, prije svega, odnosi na kratak presjek toka i razvoja događaja koji su doveli do referenduma, zatim najvažnijih odluka kako unutar, tada još uvijek Socijalističke Republike Bosne i Hercegovine, tako i iz krugova Međunarodne zajednice. Referat je donio konačne rezultate referenduma, te se dotakao njegovih neposrednih posljedica na Bosnu i Hercegovinu. Drugim riječima, u najkraćem je predstavljen i istaknut stvarni značaj pomenutog referenduma, koji se ogleda u tome da je on otvorio put ka osamostaljenju Republike Bosne i Hercegovine, ka njenom međunarodnom priznanju i prijemu u članstvo Ujedinjenih nacija, zatim u tome što je referendum učinio legitimnim i Vladu i Armiju Republike Bosne i Hercegovine, a samim time i odbranu države od unutrašnjih i vanjskih snaga koje su je pokušavale uništiti.

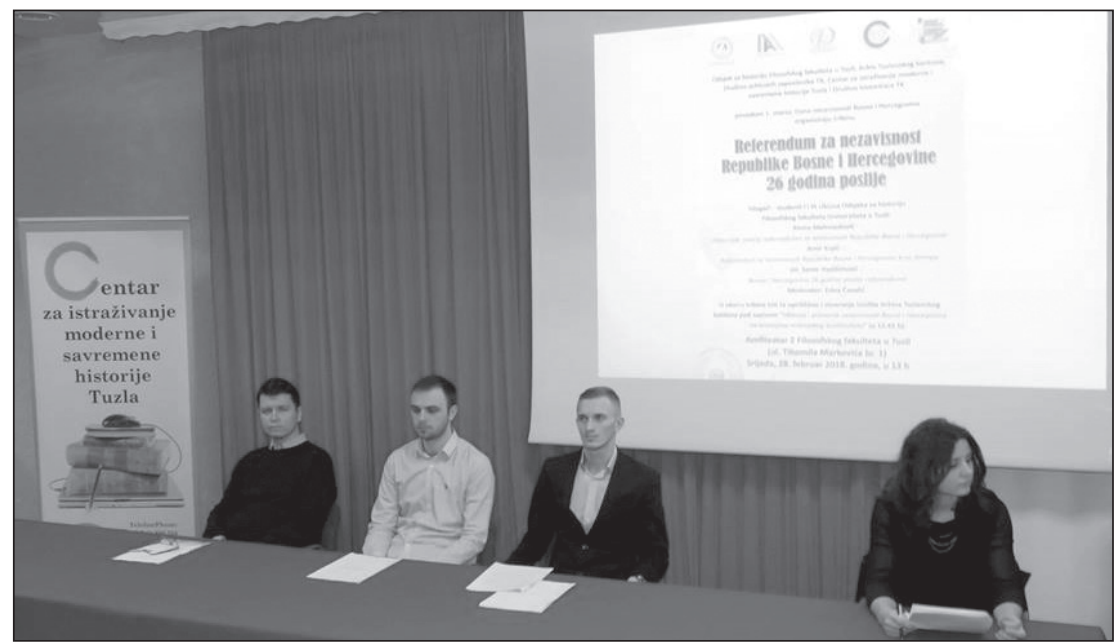

Prilog 2. Učesnici tribine "Referendum za nezavisnost Republike Bosne i Hercegovine - 26 godina poslije".

Drugi referat nosio je naslov Referendum za nezavisnost Republike Bosne $i$ Hercegovine kroz štampu, a njegov autor i izlagač bio je Amir Krpić, uz recenziju 
prof. dr. Seada Selimovića. Krpić je predstavio najznačajnije novinske članke i naslove iz predreferendumskih dana, tokom dva referendumska dana i neposredno nakon njega. Riječ je o člancima iz sarajevskog lista Oslobođenje, tuzlanskog lista Front slobode i banjalučkog lista Glas. Izlaganje je praćeno video-prezentacijom kako bi prisutni i sami mogli ukratko pogledati najistaknutije naslove ili najinteresantnije dijelove članaka. Cilj tog izlaganja bio je upoznati prisutne ne sa referendumom samim po sebi, već sa pisanjima tadašnje štampe.

Nakon toga je uslijedilo izlaganje mr. Semira Hadžimusića, koji je predstavio svoj referat pod naslovom Referendum za nezavisnost Republike Bosne $i$ Hercegovine: 26 godina poslije, koji je napisan uz recenziju prof. dr. Izeta Šabotića. Hadžimusić je u najkraćem predstavio put Bosne i Hercegovine nakon referenduma, odnosno stanje u kojem se država Bosna i Hercegovina nalazi danas, 26 godina nakon sudbonosnog i historijski značajnog referenduma za nezavisnost. Izlagač je ukazao na najvažnija dostignuća postdejtonske Bosne i Hercegovine, prije svega na planu euro-atlantskih integracija, ali i na unutrašnje stanje i uređenje države uspostavljeno Opštim okvirnim sporazumom za mir u Bosni i Hercegovini, ističući njegove prednosti i nedostatke. Kao najvažniju prednost, izlagač je istakao činjenicu da je Sporazum zaustavio rat u Bosni i Hercegovini i omogućio daljnji razvoj zemlje. Sa druge strane, kao glavni nedostatak Sporazuma istaknuto je očuvanje entiteta Republika Srpska, u prvom redu zbog načina na koji je stvarana, a koji su suprotni svim civilizacijskim vrijednostima, posebno u savremenom svijetu. Također, Hadžimusić je kao negativnu stranu Sporazuma naveo i nejednako i sa europskim standardima neusklađeno uređenje postdejtonske Bosne i Hercegovine, koje u mnogo čemu ometa razvoj države u pravcu euro-atlantskih integracija. Osim toga, Hadžimusić je ukazao na problem neadekvatnog i pomalo stidljivog obilježavanja Dana nezavisnosti, ali i drugih značajnih datuma iz bosanskohercegovačke historije. On je naveo da se tim datumima poklanja nedovoljno pažnje, a i onda kada se obilježavaju, to se čini nestručno, čak i do te mjere da se državna zastava ne ističe prema propisima.

Cjelokupno gledajući, ova tribina imala je nekoliko ciljeva. U prvom redu dolazi činjenica da je najvažnije datume iz historije Bosne i Hercegovine neophodno obilježavati i na taj način ih čuvati od zaborava. Iako to treba da bude obaveza svih, može se konstatovati da Odsjek za historiju ima posebnu obavezu da njeguje historijski značajne datume. Osim toga, tribina je imala cilj i da podstakne druge institucije i društvene krugove na čuvanje sjećanja na referendum za nezavisnost Republike Bosne i Hercegovine, a u konačnici je cilj bio da se kroz čuvanje sjećanja ujedno sačuva i istina o tom događaju, te da se i na akademskom i na drugim društvenim nivoima podstiče i dodatno razvija svijest o vrijednosti i značaju 1. marta kao datuma, Dana nezavisnosti, zatim samog čina referenduma koji je do toga doveo, te njegovog značaja za daljnji razvoj događaja u Bosni i Hercegovini, te razvoja države i na unutrašnjem i na vanjskom planu. 